\title{
The combination effect of whey kefir and tomato (Solanumlypopersicum) on expression of tumor necrosis factor alfa (TNF- $\alpha$ ) and bronchioles histopathology in rats (Rattusnorvegicus) astma model induced by ovalbumin and lipopolysaccharide
}

\begin{abstract}
Asthma is a chronic respiratory disease that is the result of type 1 hypersensitivity reactions that are often found in animals and humans. Induction of an animal model of asthma using ovalbumin (OVA) and compounded with lipopolysaccharide (LPS) from Phorphyromonas gingivalis bacteria.The combination of whey kefir and tomatoes contain vitamin $\mathrm{C}$, lycopene, carotene and other antioxidants and polysaccharides that act as anti-inflammatory. This study aimed to determine the effect of a combination of Whey Kefir and tomatoes in treating bronchial asthma against histolopatologis imaging and the expression of proinflammatory cytokines TNF- $\alpha$. The research method using a completely randomized design using 5 groups which namely negative control, mice were induced OVA intraperitoneally $10 \mathrm{mg} / 200 \mathrm{grBB}$ mice on day $1,14,21$ and LPS $1 \mathrm{ug} / 200 \mathrm{grBB}$ rats given intrasulkuler on day 10,11 as a positive control treatment of asthma and the three other groups of mice induced by ovalbumin and treated with a combination of LPS and whey kefir and tomatoes for 14 days with a gradual volume is $1 \mathrm{ml} / 200 \mathrm{gr} \mathrm{BB}, 1,5 \mathrm{ml} / 200 \mathrm{grBB}$ and $2 \mathrm{ml} / 200 \mathrm{grBB}$. Measurement of levels of TNF- $\alpha$ expression using immunohistochemical method and then the data were analyzed using ANOVA and bronchioles organ histopathology observations using Hematoxylin eosin staining was observed subsequent bronchial epithelial and smooth muscle thickness with a microscope at 400x magnification. The results from this research showed that combination therapy and tomato whey kefir are able to decrease the percentage of TNF- $\alpha(p<0.01)$ and improved bronchial epithelial and smooth muscle in the mice model of asthma. Best therapy volume is $1,5 \mathrm{ml} / 200 \mathrm{grBB}$. The conclusion of this study is that the combination of whey kefir and tomatoes can be used as a therapeutic mouse model of asthma
\end{abstract}

Keywords: asthma, bronchial, kefir, TNF $\alpha$, tomatoes
Volume 9 Issue 3 - 2018

\author{
Chanif Mahdi \\ Faculty of Mathematic and Natural Sciences Brawijaya \\ University, Indonesia
}

\begin{abstract}
Correspondence: Chanif Mahdi, Faculty of Mathematic and Natural Sciences, Brawijaya University, Indonesia,
\end{abstract} Email chanifmahdi@gmail.com

Received: February 20, 2018 | Published: June 29, 2018

\section{Preface}

Asthma is a chronic inflammatory disease of the respiration organ that causes constriction of the airways Nelson. ${ }^{1}$ Based on the report of Riskesdas, ${ }^{2}$ the prevalence of asthma in Indonesia is $4.5 \%$ that of the 220million population of Indonesia there are 9million people who suffer from asthma. Asthma is also often attack animals, especially cats. The prevalence of asthma in cats is about $1-5 \%$ of the worldwide population Reinero. ${ }^{3}$ In 2014, there were more than 800,000 of domestic cat population in the United States suffer from acute or chronic asthma. Cat breeds which mostly suffer from asthma are Siamese and Himalayan Ewing. ${ }^{4}$

Asthma's symptoms can be characterized by shortness of breath and coughing caused by tightening of the muscles around the respiration duct, inflammation, pain, swelling, bronchial constriction, and excessive mucus secretion in the lung mucosa organ. Factors that affect asthma include gender, heredity, environment (irritant, cigarette smoke, air pollution, and climate change), and allergens Foster et al, ${ }^{5}$ (Alexander, 2006). One of the allergen is ovalbumin which is the main protein of egg whites $(54 \%)$ as sensitization material towards Th2 immune responses to activate $\mathrm{B}$ cells into plasma B cells that produce
IgE E. IgE binds to mast cells causing degranulation of mast cells and produce inflammatory mediators such as histamine, cytokines, prostaglandins, and leukotrienes. Nisbet et al. ${ }^{6}$ Inflammatory mediatorsproduct will cause inflammation that can lead to damage of the bronchioles and increase the production of pro-inflammatory cytokines such as TNF- $\alpha$ Noble, 2000, PDPI. ${ }^{7}$ Currently asthma treatment is done by using bronchodilator drugs such as salbutamol (albuterol), proterenol (orsiprenalin), terbutaline and fenoterol. But the use of these chemical drugs have some side effects, among others, hypertension and premature osteoporosis Gunawan et al. ${ }^{8}$

Tomato (Solanumlycopersicum L) is a fruit that contains vitamins $\mathrm{A}$ and $\mathrm{C}$, minerals, fiber, iron, phenolic compounds, carotenoids and bioflavonoids (lycopene, $\alpha$ and $\beta$-carotene). Vitamin $\mathrm{C}$ and lycopene acts as an immunomodulator, an antioxidant or free radical scavengers due to external stressors such as allergens Canene-Adam, et al. Kefir is a functional food that contains the bacteria and yeast as a probiotic that can increase the function of mucosal immune response through the body by producing antibodies Suhartanti. ${ }^{10}$ Tomato juice fermented with wheykefir is expected to improve the efficiency of the tomatoes content and produce bioactive peptides so that easy to be absorbed by the body. 
Therefore, this study was conducted to assess the effect of a combination of whey kefir and tomato (Solanumlypopersicum L.) as an asthma therapy that can reduce the incidence of inflammation resulting in decreased expression of cytokines TNF- $\alpha$ and improvement of histopathological bronchioles imaging.

\section{Material and methods}

\section{Tools and materials}

The equipment used in this research are including lab coats, places to eat and drink rat, fabric handling, syringe $1 \mathrm{~mL}$, syringes $3 \mathrm{ml}$, scalpel, blade, scissors sharp, sharp scissors-blunt, tweezers anatomical, tweezers chirurgis, board surgical, needle, baker glass, pots organ, object glass, cover glass, vortex, compare Omron Compressor Nebulizer, a microscope (Olympus BX51), and scales.

Materials used in this study were white rats (Rattusnorvegicus) Wistar strain weighing between 150-200grams aged 8-12weeks, ovalbumin (Sigma-Aldrich), LPS1435/1449 of the bacterium Porphyromonasgingivalis, physiological saline, $\mathrm{AlOH} 3$, PBS, distilled water, primary antibody (Rat Monoclonal anti-TNF- $\alpha$ ), ethanol (70\%, $80 \%, 90 \%$, absolute), Xylol, paraffin, colorants Hematoxylin eosin, Rabbit anti-Rat TNF, SA-HRP, whey kefir and tomatoes.

\section{Working Procedure}

\section{Treatment of animals}

Animalmodels of asthma that is used is a whiterat(Rattusnorvegicus) male Wistar strain obtained from Animal Experimental Development Unit (UPHP) UGM Yogyakarta with 8-12weeks of age and weighing between 150-200grams and has obtained a certificate of conduct worthy of the Ethics Committee UB's research No. 605 -KEP-UB.

\section{Asthma induction}

Preparation of animal asthma modelconducted by addition of ovalbumin (OVA) as much as three times. Giving OVA I carried through intraperitoneally with $1.5 \mathrm{mg} \mathrm{AlOH}_{3}$ in $200 \mathrm{~mL}$ of PBS on day 0 after acclimatization and administration of OVA II intraperitoneally on day 14. OVA III given by inhalation on day 21 using a transparent tube which is connected to Compare Compressor Nebulizer Omron. Treatment of asthma triggers are carried out with nebulized OVA in $0.9 \% \mathrm{NaCl}$ at a dose of $1 \mathrm{mg} / \mathrm{ml}$.Injection of lipopolysaccharide (LPS) of gram-negative bacteria are intraculculerPhorpyromonasginggivalis carried by $1 \mathrm{~g} / 200 \mathrm{grBB}$ on the left upper molar gingival sulcus mice on days 10 and 11. LPS from gram-negative bacteria Phorpyromonasginggivalis can be used to exacerbate asthma Utomo. ${ }^{11}$

\section{Combination therapy of whey kefir and tomatoes making}

Whey kefir made using 1liter of fresh milk kefir seeds by as much as 50 ounces Suhartanti, ${ }^{10}$ then fermented at room temperature for 2 days. Once fermented kefir layer is formed of three layers which will then be strained and taken part nodes are part of whey kefir. Tomato juice is made by putting the tomatoes into the blender with 600 grams of tomato, then strained and taken tomato juice. Once that is done a combination of whey kefir and tomatoes with a ratio of 1:1 and then performed incubation for 3 days until it comes out the clear liquid then filtered.

\section{Granting procedure of combination therapy of whey kefir and tomatoes}

Treatment with whey kefir and tomato combinationare given orally by using a stomach sonde to the experimental animals with the asthma group storage volume is $1 \mathrm{ml} / 200 \mathrm{grBB}, 1.5 \mathrm{ml} / 200 \mathrm{grBB}$ and $2 \mathrm{ml} / 200 \mathrm{grBB}$. Treatment was given once daily for 14 consecutive days.

\section{Measurement of tumor necrosis factor alpha expression (TNF $\alpha$ )}

Rat's lung organ wasput in $10 \%$ formalin solution. Making preparations for immunohistochemistry includes the process of dehydration, clearing, embedding, sectioning, stick on glass objects and immunohistochemical staining. Expression of TNF- $\alpha$ on lung immuno histochemistry preparations were observed and photographed at $400 x$ magnification with 5 field of view for each group. Calculated percentage of TNF- $\alpha$ expression per fieldfor each group conducted with immuno ratio software. Analysis of quantitative research data by using Microsoft Office Excel and SPSS for Windows test One Way ANOVA analysis of variance followed by a Tukey test with an error rate of $5 \%$.

\section{Observation of histopathology bronchioles preparates}

The results of histopathological bronchioles preparates making visually observed using Olympus BX51 microscope magnification of 400x. Sections were observed is bronchiolis constituent epithelial changes and bronchial smooth muscle thickness.

\section{Result and discussion}

\section{Effect of whey kefir and tomatoes combination against TNF- $\alpha$ Expression}

The measurement results of TNF- $\alpha$ expression bronchioles in rats (Rattusnorveegicus) after the data obtained is calculated as shown in Table 1. Increased expression of TNF- $\alpha$ in a positive control group showed higher activation of the cells of pro-inflammatory role in the inflammatory process that occurs in response to the induction of OVA and LPS from gram-negative bacteria. The activity of inflammatory cells caused by exposure to lipopolysaccharide and ovalbumin trigger a reaction phagocytosis by macrophages and neutrophils. The phagocytosis process will increase free radicals Reactive Oxygen Species (ROS).

Prolonged high levels of ROS are will activate and maintain the arachidonic acid cascade which will trigger a re-emergence of a variety of inflammatory mediators such as prostaglandins and leukotrienes. The inflammatory mediators have a chemotactic effect on macrophages, which will go to the area of inflammation and several secrete proinflammatory cytokines, one of which is TNF- $\alpha$. TNF- $\alpha$ is a pro-inflammatory cytokines which exert inflammatory cells (neutrophils and eusinofil cells) to target cells. TNF- $\alpha$ levels were high in the body may cause systemic inflammation and pathological abnormalities of septic shock Baratawidjaja \& Rengganis. ${ }^{12}$

The giving of whey kefir combination therapy and tomatoes can reduce the expression of TNF- $\alpha$ levels which decreased by $12.983 \%$ in the treatment of $1 \mathrm{ml} / 200 \mathrm{grBB}, 89.15 \%$ in the therapy of $1.5 \mathrm{ml} / 200 \mathrm{grBB}$ and $52.52 \%$ in the treatment of $2 \mathrm{ml} / 200 \mathrm{grBB}$. From these results it can be stated that therapy with $1,5 \mathrm{ml} / 200 \mathrm{grBB}$ is the most effective therapy in reducing the expression of TNF- $\alpha$. Reduction on TNF- $\alpha$ expression arecaused by the result of the combination of whey kefir and tomatoes which contain antioxidant and anti-inflammatory. Biopeptidsare active ingredients contained in whey kefir has a role as anti-inflammatory with the binding of cyclooxygenase (COX-1 and COX-2) and lyphooxigenase (LOX) which resulted in a decrease PGE2 and LTB4 the bronchioles so that inflammation is reduced (Siriwardhana et al., 2012). 
Table I Percentage of TNF- $\alpha$ expression

\begin{tabular}{llll}
\hline Group & $\begin{array}{l}\text { Expression mean of } \\
\text { TNF- } \alpha\end{array}$ & $\begin{array}{l}\text { Increased expression } \\
\text { TNF- } \alpha \text { against negative } \\
\text { control }\end{array}$ & $\begin{array}{l}\text { Reduction expression } \\
\text { TNF- } \alpha \text { against positive } \\
\text { control }\end{array}$ \\
\hline $\begin{array}{l}\text { Negative Control } \\
0,7900 \pm 0,16 \mathrm{I}^{\mathrm{a}}\end{array}$ & - & - \\
Positive Control & $12,535 \pm 0,386^{\mathrm{d}}$ & $1486,7 \%$ & - \\
$\begin{array}{l}\text { Therapy } \\
\text { Iml/200grBB }\end{array}$ & $10,907 \pm 0,379^{\mathrm{c}}$ & - & $12983 \%$ \\
$\begin{array}{l}\text { Therapy I,5ml } \\
\text { 00grBB }\end{array}$ & $1,360 \pm 0,665^{\mathrm{a}}$ & - & $89,15 \%$ \\
$\begin{array}{l}\text { Therapy } \\
2 \mathrm{ml} / 200 \mathrm{grBB}\end{array}$ & $5,953 \pm 0,788^{\mathrm{b}}$ & - & $52,52 \%$ \\
\hline
\end{tabular}

Differences notations between $a, b, c, d$ showed a highly significant difference between the treatment groups $(p<0,0 \mathrm{I})$

The combination of whey kefir and tomatoes contain vitamin $\mathrm{C}$, which acts as an antioxidant. Antioxidants can be used as freeradical scavengers by stabilizing the electrons in the free radical bond so that it become stable. According to Kosasuh, ${ }^{13}$ antioxidants are compounds which can give its electrons to free radical molecules that can break the chain reaction of free radicals, so that theunpaired atom and getelectron pair which resulted on it is not reactive anymore. When the free radicals in the body decreases the damage caused by free radicals will also be reduced so that it will decreased expression of TNF- $\alpha$.

In the group $2 \mathrm{ml} / 200 \mathrm{grBB}$ treatment increased expression of TNF- $\alpha$ therapy when compared with $1,5 \mathrm{ml} / 200 \mathrm{grBB}$. That is because as a result of vitamin $\mathrm{C}$ with high doses. According to Muliartha ${ }^{7}$ injection of vitamin $\mathrm{C}$ in high concentrations will cause a loss of the ability of vitamin $\mathrm{C}$ as an antioxidant and become pro-oxidant. Pro-oxidant generated by excessive administration of vitamin $\mathrm{C}$ will increase the amount of free radicals in the body so as to enhance the expression of TNF- $\alpha$.

\section{The Effect of whey kefir and tomatoes combination against bronchial histopathology imaging.}

In this study, the hystopathological changes were observed damage to epithelial and smooth muscle hypertrophy of the bronchioles, which is shown in Figure 1.

Chronic exposure to OVA and LPS cause structural changes in the respiration tract in the form of epithelial thickening, increased goblet cells and smooth muscle thickening Temelkovski. ${ }^{14}$ On the positive control mice, shown the defect in the composition of the bronchial epithelium of ciliated columnar epithelium becomes irregular and smooth muscle thickening. This is due to the inflammation which caused by lipopolysaccharidebacterial that induced ovalbumin and Phorpiyomonasginggivalis. Exposure to the allergen and LPS activates macrophages, mast cells and eosinophils to release protease enzymes and free radicals that can damage the bronchial epithelial cells Bratawidjaya. ${ }^{12}$

Free radicals which are formed can oxidize unsaturated lipid acids (polyunsaturated fatty acids or PUFA) in the cell membrane lipid peroxidation resulting hydroperoxide, lipid peroxidation occur continuously can cause damage to the bronchial epithelium in mice models of asthma. Smooth muscle encounterhypertrophy due to the transforming growth factor- $\beta$ (TGF- $\beta$ ). Chen et al, states that the Transforming Growth Factor- $\beta 1$ (TGF- $\beta 1$ ) is a cytokine that is very important in the remodeling of the respiratory tract. Other factors that could cause the smooth muscle hypertrophy are the Mastocyte from mast cells which occurs decreasing the mediator of inflammatory mediators that can increase the volume of smooth muscle.
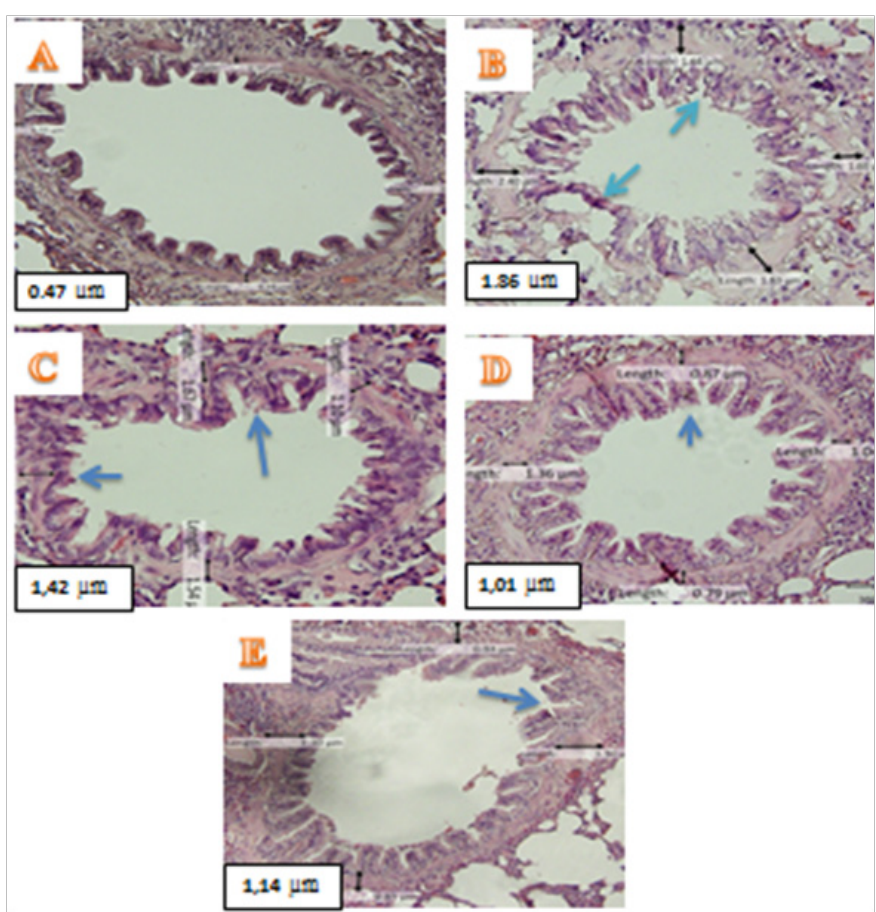

Figure I Imaging of Rat's BronciolusHystopatologyasthma models exposed to ovalbumin and lipopolysaccharide by Immunohistochemistry method (400x magnification; cross section).

\section{Notes}

A) Negative control

B) positive control

C) Therapy of whey kefir and tomatoes combination $1 \mathrm{ml} / 200 \mathrm{grBB}$

D) Therapy of whey kefir and tomatoes combination $1,5 \mathrm{ml} / 200 \mathrm{grBB}$

E) Therapy of whey kefir and tomatoes combination $2 \mathrm{ml} / 200 \mathrm{grBB}$. (J) epithelerosion. Thickness of smooth muscle 
Hystopathologic bronchioles imaging which get whey kefir and tomatoes combination therapy $1 \mathrm{ml} / 200 \mathrm{grBB}$ have started to decrease damage to the epithelial structure shown by the composition of the epithelium near normal, although there are some epithelial regardless of the basement membrane, but for the bronchial smooth muscle hypertrophy was seen having. Increased smooth muscle thickness on asthma is generally considered as progressive inflammatory response. On the condition of asthma in the accumulation of mast cells in smooth muscle that mast cells can attract TGF- $\beta 1$ resulting in smooth muscle hypertrophy.

In the grouptreatment which received therapy of $1.5 \mathrm{ml} / 200 \mathrm{grBB}$ has shown improvement close to normal bronchial epithelial structures such as the negative control. Likewise the thickness of smooth muscle suffered diminution reached $1.01 \mu \mathrm{m}$, while the treatment group $2 \mathrm{ml} / 200 \mathrm{grBB}$ already improved bronchial epithelial structures as well but still looks a little erosion of epithelial. The thickness of the smooth muscle of the group $\mathrm{E}$ is $1.14 \mu \mathrm{m}$. This shows that the $1.5 \mathrm{~mL} / 200 \mathrm{gBB}$ volume is the best volume in order to decrease asthma incidence with bronchial hystopathological image improvement approaching negative group.

Hystopathological bronchial imaging improvement in animal models of asthma is due to the antioxidant content of anti inflamation and whey kefir and tomatoes. Antioxidants inhibit damage by stabilizing free radicals in the body. While spendinginflammatory mediators will inhibit the inflammation, thereby reducing the inflammation that can cause damage to the respiratory tract.

In the group $\mathrm{E}$ therapy were given a higher volume of $2 \mathrm{~mL} / 200 \mathrm{~g}$ $\mathrm{BB}$ has also been improved the imaging but not as good as histopathology bronchioles of therapy $1,5 \mathrm{ml} / 200 \mathrm{grBB}$ it is because the provision of Vitamin $\mathrm{C}$ with the higher dose had no effect as an antioxidant yet vitamin $\mathrm{C}$ will act as a pro-oxidant that can cause tissue damage. High levels of vitamin $\mathrm{C}$ obtained from a combination of the vitamin $\mathrm{C}$ content of whey kefir and tomatoes. According to Takahashi and Tanaka ${ }^{15}$ flavonoids included in lycopene is able to inhibit the activation of IL- 4 and IL-13 issued by Th2 cells. Th2 cells that do not bind to IL-13 and IL-4 resulted in Ig-E are not produced by the $\mathrm{B}$ cells that mast cells are inactive. Inactive mast cells are lead no crosslinking with Immunoglobuline $\mathrm{E}$ in the bronchioles and does not occur degranulation of mast cells so that the pro-inflammatory cytokines (TNF- $\alpha)$ and histamine are no longer produced in the bronchioles that will reduce inflammation and decrease free radicals and repair asthma rat lung organ.

\section{Conclusion}

Combination therapy kefir whey and tomatoes with volume $1,5 \mathrm{ml} / 200 \mathrm{grBB}$ can decrease the expression of TNF- $\alpha$ and can improve hystopathologic picture bronchioles characterized by epithelial repair bronchiolusus and smooth muscle cell size were nearly normal. ${ }^{16}$

\section{Conflict of interest}

Author declares that there is no conflict of interest.

\section{References}

1. Nelson FI, Linnemannn CLL, Weldon NH. Sub Lingual Imunoterapy for Respiratory allergic. Journal Allergy Clin Immunol. 2007;117:1021-35.

2. Riset Kesehatan Dasar. Jakarta: Badan Penelitian dan Pengembangan Kesehatan, Department Kesehatan, Republik Indonesia. 2013.

3. Reinero CR. Advance in the Doagnosis and Treatment of Feline Asthma. USA: University of Missouri Columbia. Western Veterinary Conference 2013. 2013.

4. Ewing T. Feline Asthma. 2004.

5. Foster SF, Allan GS, Martin P, et al. Twenty five asthma syndrom (19952000). Journal of feline medical and surgery. 2004;6(3):181-188.

6. Nisbet AD, Saundry RH, Moir AJG, et al. The complete amino-acid sequence of hen ovalbumin. European Journal of Biochemistry. $1981 ; 115(2): 335-45$.

7. Persatuan Dokter Paru Indonesia. Pedoman Diagnosis dan PenatalaksanaanAsma di Indonesia. 2006.

8. Gunawan G, Sulistia S. Rianto, Nafrialdi dan Elysabeth. Farmakologi danTerapi. Jakarta: Departemen Farmakologi dan Terapeutik Universitas Indonesia. 2007

9. Canene-Adams K, Clinton SK, King JL, et al. The growth of the Dunning R-3327-H transplantable prostate adenocarcinoma in rats fed diets containing tomato, broccoli, lycopene, or receiving finasteride treatment. FASEB J. 2004;18(4-5):A886(591.4).

10. Suhartanti D. Perbandingan Aktivitas Antibakteri Kefir Susu Sapi Dan Kefir Susu Kambing terhadap Bakteri Staphylococcus Aureus. Yogyakarta Jurnal EKOSAINS. 2014;69(1).

11. Utomo H. Rapid Relief Mechanism of Allergic Rhinositis after "Assited Drainage" Therapy. Dental Hospital, Faculty of Dentistry, Airlangga University, Surabaya. Journal of Dentistry Indonesia. 2012;19(3):57-64.

12. Baratawidjaja KG dan I, Rengganis. Imunologi Dasar Edisi 10. Jakarta: Fakultas Kedoteran Univeritas Indonesia; 2013.

13. Kosasuh EN, Setiabudhi T, dan Heryanto H. Peranan Antioksidan Pada Lanjut Usia. Jakarta: Pusat Kajian Nasional Masalah Lanjut Usia Hal. 2004;48-49.

14. Temelkovski J, Hogan SP, Shepherd DP. An Improved Murine Model of Asthma: selective airway inflamation, ephitelial lesion and increase methacholine responsiveness following chronic exposure to aerosolised allergen. Thorax. 1998;53(10):849-56.

15. Takashi R, Tanaka T. Flavonoid and Asthma. US national Library of Medicine, National Institut of Health. 2013;5(6):2128-2143.

16. Muliartha GK. Oral Comsumption of Combined Vitamin C and E Repair Liver Damage Due to Subchronic Exposure to Cigarette Kretek. Journal Kedokteran Brawijaya. 2009;25(1):23-27.

\section{Acknowledgements}

None. 